\title{
成人になった小児期心疾患の諸問題： オーバービュー
}

\section{久留米大学医学部 小児科加藤裕久}

今回の日循のパネルディスカッションで,川島 康生会長より『成人になった先天性心疾患，川崎 病の諸問題』を取り上げて頂いた。この問題は今 後, 臨床心臓病学のなかで新しい重要な分野にな ってくるものと思われ，時機を得たテーマである。 まずはじめにそのバックグランドと今後の問題点 を総論として述べてみたいと思う1).

心臓病の多くのものは小児期から成人へと連続 した問題を抱えている。重症の先天性心疾患も最 近は手術で救命され，成人へと成長してきている. 川崎病の冠状動脈後遺症も寸でに成人の虚血性心 疾患の中に紛れ込んでいる。リウマチ性弁膜症の 多くは小児期のリウマチ熱によるし，高校生頃か ら発症してくる心筋症は, もともとは遺伝子の異 常に基づく先天性の疾患である，成人の虚血性心 疾患は動脈硬化によるもので，それがすでに小照 期からスタートしていることは多くの研究が示す と扔りである。このように考えると，心疾患を診 療する我々にとって小児科から内科への橋渡しが いかに大切かが理解できるが，実際にはそうでな いのが現実である。ここでは，今から問題となっ てくる成人となった小児期の心疾患のうち，とく に疾患の数も多い先天性心疾患と川崎病を取り上 げた.

\section{成人になった先天性心疾患の問題}

先天性心疾患は出生1,000に対し約 $10(1 \%) の$ 頻度とされているが, 1970年の出生数は193万であ
るので, 推定先天性心疾患数は約 19,000 となる. 先天性心疾患の自然死亡 (新生児, 乳幼児に多い), 自然治癒 (心室中隔欠損の自然閉鎖など)などによ る減少, さらに最近の外科治療などの進歩による 生存者の増加を考慮すると，その約60〜 70\%が成 人期に達していると考えられる。そのようなこと から，我が国の成人における先天性心疾患の数は 約 20 ～30万人と推定される. 心臓手術による生存 率が著明に向上した例として，図１に大血管転位 症の1969年と1992年の生存曲線を示した。このよ うに手術を受けて生存し, 成人期へと至っている 人が増えてきている。しかしながら，それらの例 がすべて問題がないかというとそうではなく，医 学的にも社会的心理的にもさまざまな問題を抱之 ていることも事実である ${ }^{2)}$ これれらの先天性心疾患 の成人期における問題は表 1 にまとめてみたが, まず内科的，外科的問題として術後の不整脈があ ク，ときにそれが突然死の原因ともなる。我々の 施設で開心術をうけた先天性心疾患 2,239 例中, 術 後遠隔期に突然死した例は14例あり，その半数は ファロー四徵症であった。 そのうち 9 例は不整脈 死であった。 その他肺高血圧症, 感染性心内膜炎, 心機能不全, 弁機能不全, 再手術やさらに心臓移 植などの問題もある。またこのような状態に中年 すぎに加齢に伴う高血圧や動脈硬化が加わってく るとどうなるか，などの新しい問題や，その他の 表に掲げた医学的, 社会的, 心理的な問題も重要 である。

[key words] 成人先天性心疾患, 川崎病, 循環器専門医のトレーニング 


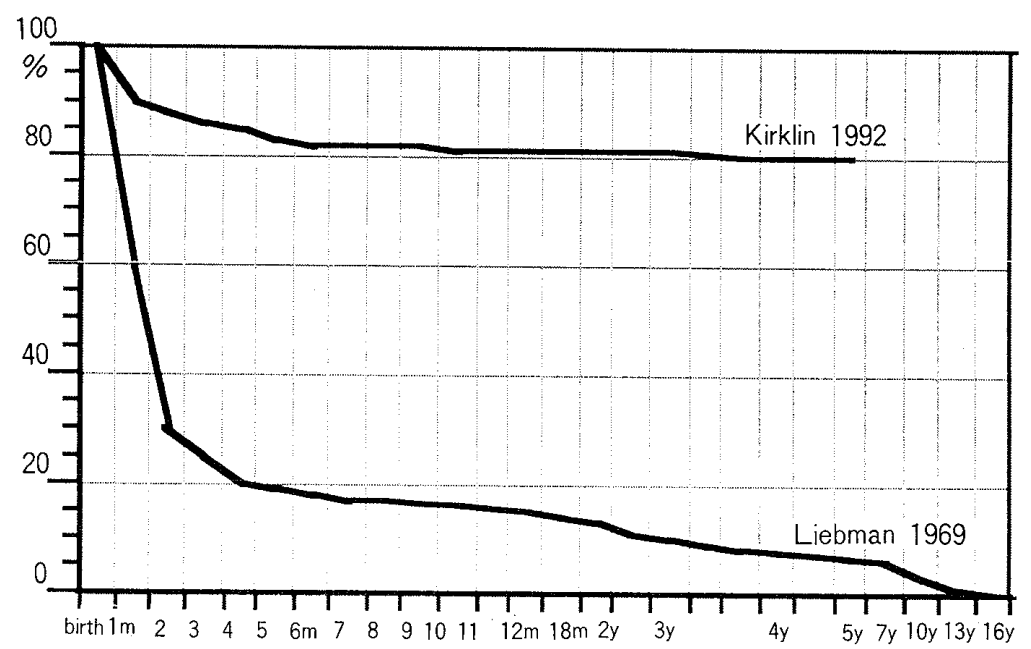

\section{表 1 成人になった先天性心疾患の長期的問題}

1.内科的, 外科的問題

不整脈(突然死)，感染性心内膜炎，肺高血圧 症, 心機能不全, 弁機能不全, 再手術や心肺移 植の問題

2. 冠動脈硬化や高血圧などのいわゆる成人病が加わ るとどうなるか?

3. 社会的, 心理的問題 就職, 保健, 心理的問題, 結婚, 出産, 子供へ の遺伝的問題

4. Who care?

小児期から内科への連携, 診療システム, adult cardiologist のトレーニングシステム

(Kato H : Jpn Circ J, 1991)

\section{川崎病心血管後遺症の成人期の問題}

川崎病は最初の報告からすでに 25 年以上経過し， 初期の例はすでに成人に達している。これらの例 では当時，冠状動脈病変が問題にされていなかっ たため, 冠状動脈の精査がなされておらず，現在， 原因不明の冠状動脈瘤もしくは虚血性心臟病とし て内科領域で取り扱われている例もあると考えら れる。また明らかな冠状動脈障害をもちながら成 人となっている例も多くみられる。川崎病は我が 国では年間約 6,000 例発症し，すでに全国集計では 13万例を越えている。我々は1973年上り冠状動脈 造影検查を導入し, 1995年までの 23 年間に 1,664 例
について急性期から血管障害のフォローアップス タディを行ってきたが, 冠状動脈瘤は全1,664例中, 273例 (16.4\%)に2られた。弁膜症は僧帽弁閉鎖不 全 15 例 (0.9\%), 大動脈弁閉鎖不全 4 例 $(0.24 \%)$ で あった。

川崎病冠状動脈瘤がどのような運命をたどるか， 長期的な予後はどうか，などまだ不明な点が多い が，筆者らは1973年より長期フォローアップを行 つており ${ }^{3}$, 特に川崎病発症後10２0年経過した川 崎病症例 (1983年以前に発症した例) 594例のうち, 89例はすでに成人に達していた。川崎病急性期(発 症 3 力月以内) に冠状動脈造影を施行し,冠状動脈 病変の評価を行った 1,545 例中，冠状動脈瘤が 244 例にみられた。これらを 2 年以上，最長 22 年間フ オローアップし， 2 回目の造影検查を $1 \sim 2$ 年後 に行い，冠状動脈病変の経過を観察した。その経 時的変化を図 1 に示寸。第 2 回造影検查では，54 \%において冠状動脈瘤の regression(動脈瘤の自然 消退）を認女, $46 \%$ には狭窄病変への進展や動脈瘤 の残存を認めている。ささらにこれらの例では数年 抢きに第 3 回，第 4 回の造影検査を行い，最終的 に狭窄病変を認め虚血性心疾患に進展したのは 6 例の心筋梗塞死亡例を含如全川崎病症例の $3 \%$ で あった。冠状動脈瘤の regression する時期や, 狭 窄病変へ進展していく時期と発症からの期間との 関係では regression は，発症より 2 年以内に $90 \%$ 
に認められている.冠状動脈瘤を認めた146例中約 $50 \%$ は 2 年以内に，冠状動脈造影上正常化してい た．狭窄例においては，その50\%は発症より 2 年 以内に認施ていが，以後徐々に進行し，最長で は発症より17年後に認めた例もあった。急性期に

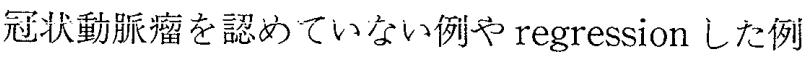
においては,特に虚血性心臟病を疑う症状もなく, また定期的な胸部 X 線検査, 心電図検査, 心工コ 一図検査においても，動脈硬化を示唆する石灰化 や狭心症や，心筋梗塞を疑う心電四変化などの所 見は認めていない，現在のところ，急性期冠状動 脈病変を認めていない例，急性期に一過性拡大を きたした例や動脈瘤が regression した例では，臨 床的な問題は残していないが，病理学的には著明 な内膜の肥厚がみられ, 動脈硬化の所見を示して いる。つまり成人の粥状動脈硬化のリスクファク ターとなる可能性もあり, 今後, 長期フォローア ップについて，コらに十分な検討が必要と思われ る。

最近，内科領域でもしだいに川崎病による冠状 動脈障害が注目されるようになり，川崎病が関与 した，または関与が疑われる若年者虚血性心臟病 の報告がみられる。厚生省川崎病研究班（班長：加 藤裕久)では, 成人領域における川崎病心血管後遺 症について，全国の内科循環器専門施設にアンケ ート調査を行った ${ }^{4)}$. 一次調查では心筋梗塞18例, 狭心症 16 例，不整脈 6 例，心機能不全 4 例，弁膜 症 2 例など48例が報告された. またこの他に109例 の原因不明の冠状動脈瘤の例が報告された。この 109例の中には, 患者が幼少時の病歴を覚えていな かったり，また両親が死亡していたりして，川崎 病らしい病歴が不明な例もあり，この109例の一部 に川崎病によるものが含まれると考えられる。こ れら48例に二次調查を行い，川崎病によると思わ れる確実例が21例みられた。発症時の䛦断は不明 熱 4 例，敗血症 2 例，肺炎 1 例，不明 12 例で 2 例 は比較的新しい例で川崎病と診断されていた。多 くは川崎病の最初の報告以前の例でここのような 診断になっていたと思われる。循環器症状は心筋 梗塞が急性，陳旧性を含めて11例，狭心症 9 例，
拡張型心筋症様の症例が 1 例であった。症状の 発現までの期間は，多くは10〜20年の間隔で発現 していた。予後は 3 例の突然死がみられ，残りは 生存しているが，僧帽弁閉鎖不全，不整脈，心不 全などの後遺症を残している例が存在した，冠状 動脈病変は多枝病変が多くみられ，多くの例で冠 状動脈に多発性の動脈瘤と狭窄, 閉塞を伴い, 動 脈瘤に一致して石灰化が認められる所見がみられ た．検討されたほとんどの例が小児期には無症状 で，川崎病発症から10年，20年して心症状の発現 をみたことは重要である。すなわち症状や兆候が なくとも10２0年後に虚血性心疾患を発症してく る可能性があり，経過観察が重要である.

成人における川崎病冠状動脈後遺症を診断する には，以下の点が重要であろうと考えられる。ま ず若年成人 (40歳以下) で虚血性心疾患をみたとき， 小児期の病歴を本人のみならず親も含女注意樑く 聞く必要がある。特に不明熱，敗血症などの診断 をされているときは，その症状が川崎病らしいも のがあったかどうかが大切である。持続する発熱， 皮虐の落屑などは特に聞く必要がある。胸部 X 線 写真での石灰化像，原因不明の僧帽弁閉鎖不全， 心電困の異常 $\mathrm{Q}$ 波, 冠状動脈造影では左右冠状動 脈に多発性の動脈瘤があり，しばしば狭窄，閉塞 を伴っている，そして動脈瘤に一致して石死化像 がみられる。このような所見を注意深くみること が重要であろう。川崎病が単に小児の疾患でなく 成人期に至るまでの一生の問題という観点から捉 える必要があることを最後に強調したい。

\section{Who care? 成人になった 小児期心疾患の診療体制}

さらに，今まで小児科医が管理していたこれら の成人になった患者を今後誰がケアするか，また どのように内科医に手渡すかなどの診療システム も今から重要な問題となってくる，最近の傾向と して, 子供の心臟病は小児循環器専門医が，内科 の循環器医はもっぱら虚血性心疾患や成人の心臓 病のみを馀療する傾向にある。したがって，最近 の若い内科循環器医は成人期に診ることのないよ 
表 2 アメリカ心臟学会 (ACC) の adult cardiologist のトレーニングにおける成 人先天性心疾患研修のカリキュラム

Level 1 Training in Congenital Heart Disease in Adults

Basic science : anatomy, pathology, physiology and genetic counseling Natural history, clinical recognition and care of patients with common defects presenting in adulthood

Postoperative residua and sequelae

Indications for and access to local and regional expert consultation

Level 2 Training in Congenital Heart Disease in Adults

Anatomy, physiology, clinical presentation and natural history of specific lesions

Diagnostic methods :

Electrocardiography

Significance of arrhythmias/electrophysiologic testing

Chest roentgenogram

Echocardiography

Catheterization/angiography

Radionuclide angiography

Other imaging methods (MRI, CT)

Therapeutic methods :

Pharmacologic management

Surgical procedures

Catheter interventional procedures

Residue and sequelae of interventions (surgical and catheter)

Reproductive issues

Counseling for pregnancy and management during pregnancy and delivery

Contraception

Evaluation for noncardiac surgery

Palliative care (e. g., management of pulmonary vascular obstructive disease)

Athletic and other activity counseling

Employment counseling and socioeconomic issues

Insurability

Psychosocial issues

$\mathrm{CT}=$ computed tomography $; \mathrm{MRI}=$ magnetic resonance imaging.

うな先天性心疾患や川崎病について十分な知識や 経験がないし，また興味もあまりもっていない。 しかし最近のように重度の先天性心疾患が手術に よって救命され，成人へとなってきているが, 我久 小児科医としてはそのまま内科医に患者を引き渡 すことに躊躇することがあるのも現状である。現 時点では小児科医が成人の先天性心疾患を診療し ている施設が多いようであるが，いずれは内科医 と一緒に，さらには内科医に引き渡すことが必要 になってくる，今からそのシステムを考えること が大切であろう。
欧米ではすでに UCLA, Toronto, Iowa, Mayo などでAdult congenital heart disease center が 発足しており，ここではトレーニングをうけた内 科医が主に診療を行っている。もち万ん小児循環 器医, 心藏外科医も参加し, さらに産科医, 胎児 の専門家，遺伝専門医，血液，腎臓，代謝の専門 家, 心理, ナーススペシャリスト, ソシャルワー カーなどのチームによる comprehensive な医療を 行うシステムを作っている，我が国でも全国に数 カ所このような施設が作られることを強く望みた い. 


\section{循環器専門医のトレーニングカリキュラムに この問題を入れるべきである}

それらの診療体制のための成人循環器専門医に 対する研修, 教育システムも必要となるであろう。 すでに欧米ではこの重要性を認識し, AHA, ACC などでもしばしばこの問題を取り上げて，啓蒙と セミナーなどのトレーニングプログラムを組んで いる。昨年 ACCが提唱した adult cardiologistsの トレーニングプログラムをみると，3 年間の fellow のトレーニングのなかで，すべての trainees にレ ベル1の研修を，さらにこの方面に興味ある人に は選択で，レベル 2 の研修を行うように勧告して いる (表 2$)^{5)}$. 我が国の循環器専門医のトレーニ ングカリキュラムには先天性心疾患の必要項目が 記載されているが，実際に現場でのトレーニング

文

1）加藤裕久:成人になった小児期の心疾患 : 臨床心 臓病学に㧍ける新しい問題(卷頭言)。心臓 1994 ; 26 : 1111-1112

2) Perloff J. K.: Congenital heart disease in adults: A new cardiovascular subspeciality. Circulation $1991 ; 84: 1881-1885$

3) Kato H., Sugimura T., Akagi T. et al. : Kawasaki disease. Coronary Artery Disease $1995 ; 6: 194-206$
はなされていないのが現状であろう。

\section{この問題は今後我が国でも重要となってくる}

さて，我が国ではこの問題を今後どのようにし たらよいであろうか，各施設で色々のやり方があ るであらうが，内科，小児科や心臟外科が協同し て関係医師に対して，まずこの問題の認識を高め, 教育の場を作ることが必要であろう。成人先天性 心疾患のクリニックを作り，内科，小児科，外科 が協同して診療するシステムを早くスタートした 方がよい．久留米大学では循環器病センターの外 来内にこのクリニックを 2 年前からスタートさせ

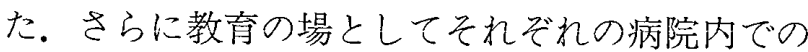
セミナーや循環器学会, 心臟病学会などでも，今 回のようにこの問題を取り上げて，啓蒙と教育の 場を作って頂くことも必要であろう。

\section{献}

4) Kato H., Inoue O., Kawasaki T. et al. : Adult coronary artery disease probably due to childhood Kawasaki disease. Lancet 1992;340 : $1127-1129$

5) Alpert J. S. : Guidelines for training in adult cardiovascular medicine, core cardiology training symposium (COCATS). JACC 1995 ; 25 : 134 